\title{
The Effects of Competition from Large, Multimarket Firms \\ on the Performance of Small, Single-Market Firms: \\ Evidence from the Banking Industry
}

\author{
Allen N. Berger \\ Board of Governors of the Federal Reserve System, Washington, DC 20551 U.S.A. \\ Wharton Financial Institutions Center, Philadelphia, PA 19104 U.S.A. \\ aberger@,frb.gov \\ Astrid A. Dick \\ Federal Reserve Bank of New York, New York, NY 10045 U.S.A. \\ astrid.dick@ny.frb.org \\ Lawrence G. Goldberg \\ Department of Finance, University of Miami, Coral Gables, FL 33124 U.S.A. \\ lgoldber@exchange.sba.miami.edu \\ Lawrence J. White \\ Stern School of Business, New York University, New York, NY 10012-1126 U.S.A. \\ lwhite@stern.nyu.edu
}

February 2005

\begin{abstract}
$\underline{\text { Abstract }}$
We offer and test two competing hypotheses for the consolidation trend in banking using U.S. banking industry data over the period 1982-2000. Under the efficiency hypothesis, technological progress improved the performance of large, multimarket firms relative to small, single-market firms, whereas under the hubris hypothesis, consolidation was largely driven by corporate hubris. Our results are consistent with an empirical dominance of the efficiency hypothesis over the hubris hypothesis - on net, technological progress allowed large, multimarket banks to compete more effectively against small, single-market banks in the 1990s than in the 1980s. We also isolate the extent to which technological progress occurred through scale versus geographic effects and how they affected the performance of small, single-market banks through revenues versus costs. The results may shed light as well on some of the research and policy issues related to community banking, and on the question of how community banks should be defined.
\end{abstract}

JEL Classification Numbers: G21, G28, L11, O33

Keywords: Banks, Community Banking, Bank Size, Multimarket Banks, Technological Progress.

The opinions expressed do not necessarily reflect those of the Federal Reserve Board, the Federal Reserve Bank of New York, or their staffs. The authors thank Christa Bouwman, Diana Hancock, and Larry Mote for helpful comments, and Nate Miller and Phil Ostromogolsky for outstanding research assistance.

Please address correspondence to Allen N. Berger, Mail Stop 153, Federal Reserve Board, 20th and C Streets. NW, Washington, DC 20551, call 202-452-2903, fax 202-452-5295, or email aberger@frb.gov. 


\section{The Effects of Competition from Large, Multimarket Firms \\ on the Performance of Small, Single-Market Firms: \\ Evidence from the Banking Industry}

\section{Introduction}

Over the last two decades, retail banking in the U.S. has changed dramatically. Large banks that branch across multiple local markets have significantly increased their share of local markets, and small banks that operate in a single market have experienced substantially reduced local market shares. As of 1982, large, multimarket banks - banks with gross total assets (GTA) over \$1 billion (real 1994 dollars) with branch offices in more than one local market - held $23.0 \%$ of local deposits in U.S. metropolitan markets. By 2000 , this had nearly tripled to $64.8 \%$. During this same interval, shares in these markets of small, single-market banks (GTA $\leq$ $\$ 1$ billion, offices in only one market) fell by more than two-thirds from $59.6 \%$ to $18.6 \%$.

The immediate enabling factor underlying this consolidation was geographical deregulation - the removal over time of individual state restrictions on intrastate and interstate banking, followed by the Riegle-Neal Act of 1994, which permits almost unlimited nationwide branching. However, deregulation cannot be the only driving force - the permission for large, multimarket banks to expand does not necessarily imply that they would choose to do so without some expected gain. Many banks had legal opportunities to expand significantly within large states such as California for many decades and chose not to do so, and most banks today continue to have much smaller scale and geographic spread than is legally allowed. Moreover, many other unregulated retail industries also had similar recent consolidation trends, including office supplies (with Staples and Office Depot taking large shares in many local markets), hardware (Home Depot, Lowe's), pharmacies (CVS, Rite Aid), toys (Toys-R-Us), and

broader retailing (Wal-Mart). It is possible that common factors may be driving some of this consolidation in retailing industries.

We offer two competing hypotheses for this consolidation trend in banking in particular and possibly to some extent in retailing more generally. Under the efficiency hypothesis, technological progress increased scale economies over time and allowed larger organizations to be managed more proficiently relative to small institutions. Improved information processing and telecommunications increased the ability of senior management to oversee larger, more automated operations, and advances in applied finance allowed institutions to manage the risks of larger portfolios more effectively. As well, these technological advances over time allowed organizations to operate more effectively at multiple locations across longer geographic distances by reducing the costs of monitoring and communicating with staff in distant branch locations. Importantly, the hypothesis is about the performance of large, multimarket firms $\underline{\text { relative }}$ to small, single-market firms. Technological change may have improved the performance 
of all categories of firms over time, and the efficiency hypothesis predicts a greater increase in performance for large firms that operate in multiple markets relative to small firms that operate in a single market.

Under the hubris hypothesis, in contrast, the increases in size and geographic spread over time were largely driven by corporate hubris or empire-building behavior by senior managers at the expense of the performance of the firm. These managers sought the personal rewards associated with larger empires and more geographic territory, and were weakly constrained in this pursuit by corporate governance structures. ${ }^{1}$ Under this hypothesis, the relative performance of large, multimarket firms declined over time relative to small, singlemarket firms either because the technological progress did not favor large, multimarket operations or because the technological gains were more than offset by increased managerial rewards and/or Williamson-type organizational difficulties of managing larger, more far-flung empires.

These hypotheses are separable in terms of the size and geographic components - either hypothesis could dominate for size or geographic dispersion, and the other hypothesis could dominate for the other component. For example, the hubris hypothesis may dominate for size, and the efficiency hypothesis may dominate for geographic dispersion. This could occur if senior managers seeking perquisites focused primarily on larger size, and if the improvements in technology mainly helped firms reduce the costs of dealing with staff in distant branch locations. We test for both the size and geographic components in our empirical analysis.

These hypotheses could be difficult to test using data from most retail industries. Financial market values and accounting data for large, multimarket firms are not generally broken out by local markets. Small, single-market firms typically do not generate any publicly available information from securities markets and often do not have certified audited financial statements to validate their accounting data.

We are able to circumvent these difficulties using quality data from the U.S. banking industry over the period 1982-2000. Drawing on regulatory reports and other sources, we are able to measure the annual performance of all small, single-market banks in U.S. metropolitan markets and the local shares in these markets of large, multimarket banks and banks with other combinations of size and geographic spread. We divide the data set into two time periods of 1982-1990 and 1991-2000 based on the extant research (summarized in Section 2) that suggests that between the 1980s and 1990s, large, multimarket banks significantly improved their

\footnotetext{
${ }^{1}$ This is similar to the hubris hypothesis of Roll (1986). However, we couch our arguments in terms of the profit performance of the consolidated firm, whether or not it achieved its size and geographic reach by mergers, opening new branches, or increasing branch office size. This is in contrast to Roll's focus on whether acquiring firms overpay for targets.
} 
performance relative to small, single-market banks, largely due to technological progress. ${ }^{2}$

The main testable predictions that distinguish between the hypotheses concern the change between the two periods in the effect of the local market share of large, multimarket firms on the performance of small, single-market firms in the same markets. Under the efficiency hypothesis, technological progress in the 1990s improved the performance of large, multimarket firms relative to small, single-market firms. As a result, a greater presence of large, multimarket firms should have exerted more competitive pressure and had more deleterious effects on the performance of small, single-market firms in their markets in the second period, 19912000, than in the first period, 1982-1990. The more intense competition from large, multimarket banks in the second time period may be manifested either in decreased revenues (e.g., lower rates on loans, lower fees on deposits) or increased expenses (e.g., higher rates on deposits, additional expenses on advertising or quality to retain customers). We explore both of these possibilities in our empirical analysis.

The hubris hypothesis predicts the opposite effect. Under this hypothesis, any improvements in relative performance based on technological progress were more than offset by managerial rewards or organizational diseconomies, so that a greater market share of large, multimarket firms exerted less competitive pressure on small, single-market banks. As a result, a greater presence of large, multimarket firms is predicted to exert less competitive pressure in the 1990s than in the 1980s, improving the performance of small, single-market firms.

We test the hypotheses by regressing the performance of small, single-market banks on the local market share of large, multimarket banks for the two time periods. We include the shares of large, single-market banks and small, multimarket banks as well. We test the changes in the coefficients on these market shares between the two periods. If the efficiency hypothesis empirically dominates, the change in the coefficient on large, multimarket banks should be negative, as the large, multimarket banks put more competitive pressure on small, single-market banks in the second period. The converse holds if the hubris hypothesis empirically dominates. The changes in the coefficients on the market shares of the other categories - large, single-market banks and small, multimarket banks - help determine whether size, geographic dispersion, or both is behind the domination of one hypothesis or whether one hypothesis may dominate for size and the other for geographic dispersion.

The analysis may also shed light on research and policy issues related to the topic of "community banking." It is often argued that small banks have advantages in providing some services that require a close tie

\footnotetext{
${ }^{2}$ As shown below, our empirical findings are robust to shifting the cutoff date between the two periods.
} 
to the local community (e.g., DeYoung, Hunter, and Udell 2004). Whether the efficiency hypothesis versus the hubris hypothesis empirically dominates may have implications for the abilities of the industry to provide these local services.

Our analysis may also give evidence on how community banks should be defined empirically. We argue that the conventional definition that is based on size alone may not be the best choice for empirically defining community banks - geographic dispersion may be equally important or more important than size in determining the advantages of banks in providing community banking services. It is just as plausible that large banks that operate in a single market have an advantage in collecting and processing soft information about the local community as it is that small banks that are spread over multiple markets have such an advantage.

In the regressions of the performance of small, single-market bank performance on the market shares of the other size and geographic spread categories, we use the coefficients on the market shares of the different combinations of bank size and geographic spread to help define community banks. On the assumption that small, single-market banks qualify as community banks, the coefficients on the market shares of the other bank categories may suggest the extent to which banks in these other categories use the same technologies to compete for the same customers. For example, if the market share of large, single-market banks has little or no measured effect on small, single-market bank performance, then single-market banks of all sizes may behave similarly, making single-market banks a good working definition for community banks. Alternatively, if the coefficient on the market share of small, multimarket banks were negligible - suggesting that all small banks appear to compete similarly - the conventional treatment of all small banks as community banks would be validated. If none of the market shares are significant, then it may suggest that there is nothing special about any of the categories. Thus, the coefficients on the market shares of the different categories could suggest that community banks should be defined on the basis of size, geographic spread, both, or neither.

Section 2 briefly reviews some of the relevant literature, and Section 3 presents the empirical model and discusses the variables and the data. Section 4 gives our empirical results, and Section 5 concludes.

\section{Brief review of related research on bank size, geography, and performance}

A large volume of research literature has been devoted to issues of bank competition, performance, size, geography, and technological change. ${ }^{3}$ To key in on the most relevant aspects of the extant research, we focus

\footnotetext{
${ }^{3}$ See Berger (2003) for a general review of technological progress in banking.
} 
our review on prior findings regarding the effects of bank size and geography on bank performance and how these effects may have changed between the 1980s and the 1990s in the U.S. due to technological progress. Under the efficiency hypothesis, technological progress improved the performance of large, multimarket banks relative to small, single-market banks, whereas under the hubris hypothesis, any such improvements were more than offset by managerial rewards or organizational diseconomies.

\subsection{Bank size and performance}

The relevant research on bank size and performance in the U.S. includes studies of cost and revenue performance, as well as the abilities of banks of different sizes to provide retail services in which both large and small banks compete, such as loans to small businesses and deposits.

Early research on bank cost scale economies using data on U.S. banks from the 1980s generally finds very little scale economies or diseconomies except at very small sizes, typically well under $\$ 1$ billion in assets (e.g., Berger, Hanweck, and Humphrey 1987). Later research suggests that there may be more extensive cost scale economies in the 1990 s, with average costs declining up to asset sizes of $\$ 25$ billion or more (e.g., Berger and Mester 1997). Analogously, studies of the cost-efficiency effects of 1980s mergers and acquisitions (M\&As) generally find little effect on average (e.g., Berger and Humphrey 1992), while later studies using 1990s data more often report cost efficiency gains (e.g., Rhoades 1998). ${ }^{4}$ Research on "back-office" technologies for producing services, such as payments processing, also suggest very large cost savings for large banking organizations during the 1990s that may directly be linked to scale economies and productivity gains from technological advances (e.g., Bauer and Ferrier 1996, Hancock, Humphrey, and Wilcox 1999).

Other research suggests that large banks may have also gained relative to small banks in terms of revenues. Profit efficiency studies and other studies including revenues find that M\&As increased profits and revenues through improved risk-expected return frontiers (e.g., Akhavein, Berger, and Humphrey 1997, Hughes, Lang, Mester, and Moon 1999). Some evidence also suggests that U.S. banks involved in M\&As improved the quality of their outputs in the 1990s in ways that increased costs, but still improved profit productivity by increasing revenues more than costs (Berger and Mester 2003). In addition, one study examines changes over time in the ability of multibank holding companies to control their affiliate banks by measuring the extent to which the profit efficiency ranks of the lead bank and the other affiliates vary together. The measured increases

\footnotetext{
${ }^{4}$ Studies of the performance effects of M\&As embody any short-run X-efficiency effects of the consolidation process as well as scale efficiency effects, and so may be less reliable guides to the long-run effects of bank size.
} 
in control between 1980s and 1990s are substantial, consistent with reduced organizational diseconomies of scale (Berger and DeYoung forthcoming). Thus, the research on both cost and revenue performance suggest that technological change may have benefited large banks more than small banks, consistent with the efficiency hypothesis.

Other research focuses on how well banks of different sizes provide specific retail services, such as loans to small businesses and deposits. These findings may be more relevant than overall cost and revenue performance to the issue of how the market presence of large banks affects the performance of small banks. Both large and small banks compete to provide these retail services, but small banks typically do not provide wholesale services to corporate customers that account for much of the costs and revenues of large banks.

The evidence on small business lending suggests that large and small banks have comparative advantages in lending to small businesses using different technologies. Large banks appear to specialize in transactions lending technologies (e.g., financial statement lending, asset-based lending, credit scoring) that are based on "hard" quantitative information. In contrast, small banks tend to use relationship lending, which is based on "soft" information culled from close contacts by the loan officer over a period of time. Among the many empirical findings supporting the use of the different technologies are studies showing that large banks relative to small banks tend to base their lending decisions more on financial ratios than on prior relationships (e.g., Cole, Goldberg, and White 2004) and tend to have shorter, less exclusive, less personal, and longerdistance associations with the borrowers (e.g., Berger, Miller, Petersen, Rajan, and Stein forthcoming). Reasons for the different technologies may include economies (diseconomies) of scale in processing hard (soft) information, difficulties in quantifying and transmitting soft information through the communication channels of large banking organizations (e.g., Stein 2002), agency problems in handling soft information in large organizations with many managerial layers (e.g., Berger and Udell 2002), and organizational diseconomies for large banks in providing relationship lending services along with the wholesale services to corporate customers (e.g., Williamson 1988).

The evidence also suggests that large banks tend to lose retail customers - both small business borrowers and depositors - in the aftermath of M\&As. Large banks involved in M\&As tend to have reductions in their small business lending (e.g., Berger, Saunders, Scalise, and Udell 1998), consistent with a runoff of relationship loans as bank size increases. The small banks in their markets appear to pick up many of these credits and presumably improve their performance as a result (e.g., Berger, Saunders, Scalise, and Udell 1998, Berger, 
Goldberg, and White 2001, Avery and Samolyk 2004). Analogously, bank mergers are associated with runoffs of deposits. Mergers often resulted in negative deposit growth for the consolidated institutions or smaller growth than non-merging competitors, with depositors potentially leaving due to higher fees and lesser service as measured by employees per branch (DiSalvo 2002). M\&As are also associated with increased frequencies of new bank charters in the same local market, as new banks presumably form in part to capture some of the runoff of retail loans and/or deposits (Berger, Bonime, Goldberg, White 2004).

Some evidence also suggests that in the 1990s, large banks may have been able to reverse some of these losses. Large banks may be using new lending technologies to "harden" their credit information about small businesses. An example is small business credit scoring, a new technology in the 1990s in which the personal credit and payment history of the small business owner is combined with data about the business and entered into a loan-repayment prediction model. The research indicates that large banks adopted this technology earlier than small banks (e.g., Akhavein, Frame, and White 2005) and used it to expand their lending to small business borrowers, particularly to firms that are likely to be relatively opaque - credits of under $\$ 100,000$ with relatively high interest rates and poor risk ratings on average and often located outside the bank's local markets (Frame, Srinivasan, and Woosley 2001, Frame, Padhi, and Woosley 2004, Berger, Frame, and Miller 2005). Some research using 1990s data also suggests that a greater local market share for large banks is associated with lower interest rates on small business loans by both small and large banks (e.g., Berger, Rosen, and Udell 2005). This is consistent with more aggressive competition in markets with greater shares for large banks, which may adversely affect the performance of small banks through lower interest revenues.

Banks may have also used new technology in the 1990s to attract or maintain depositors. For example, large banks were well ahead of small banks in adopting Internet websites - first informational sites and then later sites that allow depositors to make transactions on-line (e.g., Courchane, Nickerson, and Sullivan 2002, Furst, Lang, and Nolle 2002). These transactional websites appear to complement the already more extensive branching and ATM networks of large banks (i.e., customers that use virtual sites also use physical sites). Bank customers may have also become more comfortable with the use of technologies such as ATMs and websites in the 1990s, reducing the likelihood of deposit runoff.

Consistent with these arguments, runoffs of deposits following bank mergers appear to have declined in the latter half of the 1990s. U.S. banks that merged in the prior year had positive deposit growth in every year from 1995-1999, as opposed to negative growth every year from 1991-1994. While the rate of growth for 
merged banks still was well below that for non-merged banks, the gap narrowed considerably during this period (DiSalvo 2002, Table 1). Thus, the research on both small business lending and deposits - services in which both large and small banks compete - provides additional evidence that innovations over time may have helped large banks relative to small banks, consistent with the efficiency hypothesis.

\subsection{Bank geography and performance}

There is less research on the effects of bank geography on performance than on the effects of bank size. Some studies focused on overall bank performance. Studies on the effects of geographic reach of large banking organizations in the U.S. generally found better risk-expected return frontiers for banks operating in more states (e.g., Hughes, Lang, Mester, and Moon 1996, 1999, Demsetz and Strahan 1997). Cross-section analysis of the effects of the distance of a bank holding company affiliate from headquarters finds slightly negative effects on cost and profit efficiency, consistent with distance-related diseconomies in management (Berger and DeYoung 2001). Further research finds that these negative effects decreased slightly between the 1980s and 1990s, consistent with at least slightly reduced distance-related diseconomies (Berger and DeYoung forthcoming).

Other studies focused on the provision of retail services in which both large and small banks compete. Some studies found that U.S. banks have increased the distances at which they make small business loans, more often lending outside the traditional geographic definition of local U.S. markets of Metropolitan Statistical Areas (MSAs) or non-MSA counties (e.g., Petersen and Rajan 2002, Hannan 2003). One study specifically linked this phenomenon to technological change for large banks, finding that the use of small business credit scoring by large banks in the 1990s is associated with increased out-of-market lending (Frame, Padhi, and Woosley 2004). As well, U.S. banks in the 1990s have more often provided household financial services other than transactions accounts from significant distances (Amel and Starr-McCluer 2002).

There is also some evidence that in recent years multimarket banks have been setting uniform deposit prices across local markets within the same state (e.g., Radecki 1998, Heitfield 1999). In some cases, the prices of multimarket banks are significantly related to state-level concentration as well as to local-market concentration (e.g., Hannan and Prager 2004, Heitfield and Prager 2004). These findings suggest that multimarket banks in the 1990s may have improved their coordination across markets. However, some recent studies also found that single-market banks have lower deposit rates in local markets with greater shares for multimarket banks, which may improve the performance of the single-market banks (Hannan and Prager 2004, Park and Pennacchi 2004). Park and Pennacchi (2004) also provide a theoretical model in which the presence of large, multimarket banks 
results in both lower loan rates and lower deposit rates due to advantages in non-deposit fund raising. This joint result, if it occurs empirically, would yield an ambiguous effect of greater market shares for large, multimarket banks on the performance of small, single-market banks (lower revenues and lower costs). Thus, most, but not all of the research on geography is consistent with the prediction of the efficiency hypothesis that greater local market shares for multimarket banks in the 1990s would have more deleterious effects on the performance of small, single-market banks in their markets than in the 1980s.

\section{Empirical model, variables, and data sets}

\subsection{Empirical model}

The basic empirical model employed in the tests is given by:

$$
\begin{aligned}
\text { Performance of small, single-market } \text { bank }_{\mathrm{b}, \mathrm{m}, \mathrm{t}}= & f(\text { market shares by bank size and geography } \mathrm{m}, \mathrm{t}-1,, \\
& \text { control variables for } \text { market }_{\mathrm{m}, \mathrm{t}-1}, \\
& \text { control variables for bank } \mathrm{b}_{\mathrm{b}, \mathrm{m}, \mathrm{t}-1}, \\
& \text { control variables for time } \\
\mathrm{t} & \text {. }
\end{aligned}
$$

The endogenous variables measure the profit and cost performance of small, single-market bank $\mathrm{b}$ in market $\mathrm{m}$ at time t. The key exogenous variables describe the distribution of market shares by bank sizes and the geographic dispersion in market $\mathrm{m}$. For simplicity and parsimony in specification, we use two classifications of bank sizesmall versus large - and two classifications of geographic dispersion - single-market versus multimarket. All banks are classified as either 1) small, single-market; 2) large, single-market; 3) small, multimarket; or 4) large, multimarket. The market shares are based only on deposits because the locations of other banking products are not generally available, although bank customers often cluster their purchases of financial services from the same institution. Market shares are used in traditional industrial organization measures of competition, but our breakout by size-geographic categories represents an innovation. The control variables account for other differences between market $m$ and other markets (concentration, demographics, regulations), between bank $b$ and other small, single-market banks (bank size and age, plus fixed effects for every bank), and between time $\mathrm{t}$ and other points in time (fixed effects for every year). The t-1 subscript on the exogenous variables in equation (1) (other than the time controls) denotes that they are measured as of the prior year to minimize unintentional 
feedback from the endogenous variables. ${ }^{5}$

Equation (1) is estimated separately using annual data for 1982-1990 and for 1991-2000. The main testable prediction that distinguishes between the efficiency hypothesis and the hubris hypothesis concerns the change between the two periods in the effect of the presence of large, multimarket firms on the performance of small, single-market firms in the same markets. Under the efficiency hypothesis, technological change between the periods tended to improve the performance of large, multimarket firms relative to that of small, single-market firms. As a result, a greater share for large, multimarket banks should have exerted more pressure and had more deleterious effects on the performance of small, single-market firms in their markets in the second period, 19912000, than in the first period, 1982-1990. The hubris hypothesis gives the opposite prediction because any technology-based relative improvements were more than offset by higher managerial rewards or greater organizational diseconomies.

Importantly, the use of the four categories of bank size and geographic dispersion also allows us to test whether the effects of size, geographic dispersion, both, or neither changed between the two time periods of 1982-1990 and 1991-2000. Consider, for example, the case in which the efficiency hypothesis applies to bank size, rather than geography. In this case, the market presence of the "large" categories - large, single-market and large, multimarket - would have more deleterious effects on the performance of small, single-market firms in the second period than in the first period, but the effects of small, multimarket banks would be relatively unchanged.

\subsection{Variables}

Descriptions and summary statistics for the variables are shown in Table 1 . The data are annual observations for banks with gross total assets $(\mathrm{GTA}) \leq \$ 1$ billion that operate in a single Metropolitan Statistical Area (MSA) for the first time period $(1982-1990)$ and second time period $(1991-2000) .{ }^{6}$ We show sample means, minimums, and maximums by bank and by market for both time periods. Statistics by bank are based on

\footnotetext{
${ }^{5}$ A bias may occur in the estimation of (1) to the extent that the market shares on the right hand side respond to the performance variable on the left hand side. Under the well-known efficient-structure hypothesis, the market shares of better performing firms tend to increase over time. This bias is not likely to be substantial because we measure performance against other small, single-market banks nationwide, rather than against the performance of large or multimarket banks in the same market. In addition, the market shares on the right hand side are measured before the performance variable on the left hand side. Finally, the efficient-structure hypothesis may take a number of years to substantially affect the local market structure, which tends to stay relatively constant over time in local U.S. banking markets.

${ }^{6}$ We use gross total assets (GTA) as our measure of bank size, which includes the allowance for loan and lease losses. Thus, we include the total size of loans, independent of expected credit losses, rather than excluding the allowance for these losses as in some research that uses total assets exclusive of the allowance.
} 
one observation per small, single-market bank per year, and represent the samples used in the regressions. Statistics by market are based on one observation per market per year for all MSAs with at least one small, single-market bank. ${ }^{7}$ Statistics by market may more accurately represent the market-based variables, given that all markets are weighted equally for each year, as opposed to the statistics by bank, which give greater weight to markets with more small, single-market banks in those years. We therefore focus on the by-bank summary statistics for the variables specific to the small, single-market banks under study - the bank's performance, size, and age - and focus on the by-market statistics for the variables that are identical for all the banks in the market market shares, concentration, demographics, and regulations. All financial values are expressed in real 1994 dollars, deflated using the Consumer Price Index (CPI). ${ }^{8}$ Notably, there are significantly more by-bank observations in the 9 years of the first time period than in the 10 years of the second time period because of the substantial industry consolidation over time. As discussed below, we check the robustness of our findings using "survivor" subsample of banks that were present in both periods and by shifting the cutoff date to make more equal samples.

The dependent variables measuring the performance of small, single-market banks include two measures of profitability - return on equity (ROE) and profit efficiency (PROFIT EFF) - as well as two measures of cost performance - the ratio of total interest plus noninterest expenses divided by gross total assets (COST/GTA) and cost efficiency (COST EFF). We view ROE and PROFIT EFF as the main indicators of performance, since they include both revenues and costs. Under the efficiency hypothesis, more intense competition from large, multimarket banks in the second time period may be manifested either in decreased revenues, increased costs, or both. For example, revenues from interest or fees may decrease if small, single-market banks respond to the additional competitive pressure by reducing interest rates on loans or by lowering fees on deposits, loans, or other products. Similarly, interest or noninterest expenses may increase if these banks respond by paying higher rates on deposits or by incurring additional noninterest expenses on advertising or to provide higher-quality services to try to retain depositors, borrowers, or other customers.

The main difference between the standard financial ratios (ROE, COST/GTA) and the efficiency

\footnotetext{
${ }^{7}$ Each by-market observation for the variables based on markets (e.g., SHARE LRG, MULT) is the unique value for that variable for the market and year, and each observation for the variables based on banks (e.g., ROE) is the average for all small, single-market banks for the market and year.

${ }^{8}$ The bank balance sheet and income items are taken primarily from the Call Reports, and the locations of bank offices and deposits are drawn from the FDIC Summary of Deposits data set.
} 
measures (PROFIT EFF, COST EFF) is that the efficiency measures in effect remove some of the differences in conditions facing the individual banks. PROFIT EFF is based on predicted values from a profit function:

$$
\begin{gathered}
\ln \left[\pi / \mathrm{w}_{3} \mathrm{z}_{3}+\theta\right]=\mathrm{f}\left[\ln \left(\mathrm{w}_{1} / \mathrm{w}_{3}\right), \ln \left(\mathrm{w}_{2} / \mathrm{w}_{3}\right) ; \ln \left(\mathrm{y}_{1} / \mathrm{z}_{3}\right), \ldots, \ln \left(\mathrm{y}_{5} / \mathrm{z}_{3}\right) ; \ln \left(\mathrm{z}_{1} / \mathrm{z}_{3}\right), \ln \left(\mathrm{z}_{2} / \mathrm{z}_{3}\right) ;\right. \\
\left.\ln \left(\mathrm{v}_{1}\right), \ln \left(\mathrm{v}_{2}\right)\right]+\ln (\mathrm{u})+\ln (\varepsilon)
\end{gathered}
$$

where $\pi$ is the variable profits of the small, single-market bank - the interest and fee income on the variable outputs minus the interest and noninterest expenses on the variable inputs. The constant $\theta$ is added to every bank's profit ratio so that the natural $\log$ is taken of a positive number. The arguments of the profit function $\mathrm{f}(\cdot)$ include w, a vector of local market prices of the 3 variable inputs: purchased funds, core deposits, and labor; $y, a$ vector of the quantities of the 5 variable outputs: consumer loans, commercial and industrial loans, real estate loans, other loans, and securities; $z$, a vector of the quantities of the 3 fixed netputs (outputs or inputs): offbalance-sheet items, physical capital, and financial equity capital; and v, a set of 2 control variables for the market environment: population and total deposits. ${ }^{9}$ The composite error term includes $\ln (\mathrm{u})$ : an efficiency residual that increases or reduces the bank's profits according to managerial skills; and $\ln (\varepsilon)$ : a random error.

Variable profits and the quantities of the variable outputs and fixed netputs are divided by the last fixed netput, equity capital $\left(\mathrm{z}_{3}\right)$. As well, variable profits and the prices of variable inputs are normalized by the last input price, the price of labor $\left(\mathrm{w}_{3}\right)$. These normalizations reduce heteroskedasticity problems, ensure price homogeneity, and help address potential problems of scale bias and other issues (Berger and Mester 1997). Note that the dependent variable includes the (variable profits)/(equity) ratio, which is closely related to ROE, the (total profits)/(equity) ratio.

The profit function $\mathrm{f}(\cdot)$ is estimated separately for each year to allow for changes in technology and economic conditions. The function is applied only to data on small, single-market banks, since banks that are large and/or multimarket may produce different products or use different technologies, which could confound the estimation. We estimate $f(\cdot)$ using the Fourier-flexible functional form, which combines a conventional translog form with Fourier trigonometric terms, and has been shown to fit the data for U.S. banks better than the

\footnotetext{
${ }^{9}$ This is often called the "alternative" profit function because it includes output quantities y, rather than output prices p. We use the alternative profit efficiency concept primarily because output prices and quality are difficult to measure accurately for commercial banks, and because output quantities are relatively fixed in the short-run and cannot respond quickly to changing prices as is assumed in the use of standard profit efficiency.
} 
translog. ${ }^{10}$ The efficiency residual $\ln (\mathrm{u})$ is distinguished from the random error $\ln (\varepsilon)$ using a form of the distribution-free approach, in which we assume that 1) the managerial efficiency of a bank is persistent over time and random error is not, and 2) random error is responsible for the most extreme (good and bad) outcomes. Thus, after estimating the profit function by OLS, we estimate $\ln (\mathrm{u})$ by averaging each composite residual with the immediately preceding and following residuals, then censor these average residuals at the $5^{\text {th }}$ and $95^{\text {th }}$ percentiles of the sample distributions (i.e., set the most extreme values to the $5^{\text {th }}$ and $95^{\text {th }}$ percentile points).

We use the estimated coefficients from equation (2) and the estimates of the efficiency residual $\ln (\mathrm{u})$ to calculate predicted variable profits, or estimates of variable profits exclusive of the random error $\ln (\varepsilon)$. Profit efficiency for bank $b$ is the ratio of b's predicted variable profits divided by the predicted variable profits for a best-practice bank with the maximum $\ln (\mathrm{u})$ under the same conditions:

$$
\begin{aligned}
\text { PROFIT EFF } & \text { ER } \left.^{b} / \hat{\pi}^{\max }=\left\{\exp \left(\hat{f}\left[\mathrm{w}^{\mathrm{b}}, \mathrm{y}^{\mathrm{b}}, \mathrm{z}^{\mathrm{b}}, \mathrm{v}^{\mathrm{b}}\right]\right) \bullet \exp \left(\ln \left(\hat{u}^{\mathrm{b}}\right)\right)\right\}-\theta\right] / \\
& \left.\left\{\exp \left(\hat{f}\left[\mathrm{w}^{\mathrm{b}}, \mathrm{y}^{\mathrm{b}}, \mathrm{z}^{\mathrm{b}}, \mathrm{v}^{\mathrm{b}}\right]\right) \bullet \exp \left(\ln \left(\hat{u}^{\max }\right)\right)\right\}-\theta\right]
\end{aligned}
$$

That is, we estimate the ratio of variable profits of $b$ to what a best-practice small, single-market bank with maximum $\ln (\mathrm{u})$ would earn if it produced the same outputs $\mathrm{y}$, faced the same input prices $\mathrm{w}$, had the same fixed netputs $\mathrm{z}$, and were in the same market environment v. A bank with the mean PROFIT EFF in the first time period of 0.6238 is estimated to earn about $62 \%$ of best-practice variable profits for its conditions, typical of findings in the efficiency literature.

Cost efficiency is calculated similarly. The arguments of the cost function $\mathrm{c}(\cdot)$ are the same as those of the profit function $\mathrm{f}(\cdot)$, and the same methodology is used to obtain predicted variable costs. A best-practice bank for purposes of COST EFF is one with the minimum efficiency residual, rather than the maximum residual used for PROFIT EFF. ${ }^{11}$ Thus, COST EFF ${ }^{\mathrm{b}}$ is the ratio of predicted best-practice variable costs to bank b's predicted variable costs for the same vector of conditions $\left[\mathrm{w}^{\mathrm{b}}, \mathrm{y}^{\mathrm{b}}, \mathrm{z}^{\mathrm{b}}, \mathrm{v}^{\mathrm{b}}\right]$, or $\hat{\mathrm{C}}^{\mathrm{min}} / \hat{\mathrm{C}}^{\mathrm{b}}$. A bank with the mean COST EFF in the first time period of 0.8157 is estimated to be about $82 \%$ efficient or equivalently wastes about $18 \%$ of its variable costs relative to a best-practice bank under its conditions, again a typical finding.

\footnotetext{
${ }^{10}$ We include the translog terms for all of the variables, but include the Fourier terms only for the $y$ and $\mathrm{z}$ terms, given that the input prices have relatively little variation. We include all the first- and second-order Fourier terms, but in the interest of parsimony, we include only the "own" third-order terms (e.g., $\left.\cos \left(\mathrm{x}_{\mathrm{n}}+\mathrm{x}_{\mathrm{n}}+\mathrm{x}_{\mathrm{n}}\right)\right)$, and exclude the third-order interactions (e.g., $\left.\cos \left(x_{n}+x_{m}+x_{q}\right), m, q \neq n\right)$. See Berger and Mester (1997) for more details.

${ }^{11}$ Note that the best-practice banks in terms of cost minimization are not necessarily the same institutions as the best-practice banks in terms of profit maximization.
} 
The use of the efficiency measures rather than ROE and COST/GTA in the performance regression equation (1) differs mainly in that the efficiency measures statistically remove some of the factors over which management likely has little control, at least in the short run. PROFIT EFF and COST EFF directly exclude the revenues and costs on fixed netputs by using variable profits and costs, rather than total profits and costs. The efficiency measures also remove the estimated effects of differences in input prices, output quantities, fixed netput quantities, and market environment, which may be difficult to change quickly. The EFF measures also reduce the effects of random error by averaging the current, preceding, and following residuals for the same bank and by censoring the extreme values in the top and bottom $5 \%$ of the distributions. In some robustness checks below, we try removing some of these differences.

As shown in Table 1, we exclude some extreme outliers in terms of bank performance. We exclude observations in which banks that lose more than $100 \%$ of their equity in one year or earn more than a $50 \%$ annual rate of return (ROE outside the interval $[-1.0,0.50])$. Similarly, we delete observations in which equation (2) predicts bank $b$ to lose more or earn more than $100 \%$ of equity in predicted variable profits $\left(\hat{\pi}^{b}\right.$ outside the interval [-equity, equity]) or predicts best-practice variable profits to be below $5 \%$ of equity $\left(\hat{\pi}^{\max }<5 \%\right.$ of equity). On the cost side, we exclude banks with costs below 2 cents or above 20 cents per dollar of assets (COST/GTA outside [0.02, 0.20]), with predicted best-practice variable costs below 2 cents per dollar of assets $\left(\hat{\mathrm{C}}^{\mathrm{min}}<2 \%\right.$ of GTA) or with predicted variable costs of more than assets $\left(\hat{\mathrm{C}}^{\mathrm{b}}>\mathrm{GTA}\right)$. The excluded values likely reflect either data errors, poor predictions for the profit or cost function, or idiosyncratic events that are unrelated to the hypotheses at issue here.

The table shows the considerable improvement in performance of small, single-market banks between the two time periods. Using the by-bank statistics, the average ROE rose from $7.89 \%$ to $10.62 \%$, while average COST/GTA fell from $6.49 \%$ to $4.35 \%$, likely due to more favorable business cycle conditions, relatively low interest rates, and productivity gains. The EFF measures show only minor improvements, but these are measured relative to the best-practice frontiers, and so do not include overall changes in performance that would be reflected in the movement of these frontiers. Importantly, our hypothesis tests below are not based on the change in performance between the two time periods, but on the changes in the responses of performance to market shares by bank size and geography, controlling for a number of factors.

As noted above, our key exogenous variables are the market shares of deposits in the four categories, which we denote by SHARE SML, SING; SHARE LRG, SING; SHARE SML, MULT; and SHARE LRG, 
MULT. We use GTA of $\$ 1$ billion to separate small and large banks. The share of small, single-market banks (SHARE SML, SING) is excluded to avoid perfect colinearity, and the tests are run on the other shares of the other three categories. Both of the small bank categories (SML, SING and SML, MULT) would correspond to the standard empirical definition of community banks as small institutions, but as discussed above, we let the different coefficients on the share variables give us guidance as to a potentially superior working definition. On the assumption that small, single-market banks qualify as community banks, the market share of any other category with little or no measured effect on the performance of small, single-market banks would suggest that that category behaves similarly and therefore would be included in the definition. If all of the shares have little or no effect, then the evidence would suggest that perhaps there should be no special category for community banks.

Not surprisingly, the table shows a substantial decline in the share of small, single-market banks of almost half between periods - from $50.96 \%$ to $27.33 \%$ using the by-market statistics, as the banking industry consolidated and shifted deposits into larger and more geographically dispersed institutions. What may be surprising is that the consolidation appears to be more pronounced in terms of geographic dispersion than in terms of size. The total local market shares of large banks (SHARE LRG, SING plus SHARE LRG, MULT) increased by $18.00 \%$ from $38.82 \%$ to $56.82 \%$, while the shares of multimarket banks (SHARE SML, MULT plus SHARE LRG, MULT) increased by $27.27 \%$ from $41.71 \%$ to $68.98 \%{ }^{12}$

We control for market concentration using the Herfindahl index for market deposits (HERF). It is important to control for this standard indicator of concentration in banking research when examining the effects of shares of individual categories, as these shares are likely to be correlated with concentration. Notably, local market concentration remains approximately unchanged on average from the first period to the second period, a

\footnotetext{
${ }^{12}$ The average size of large banks and the average number of markets for multimarket banks in these markets also increased considerably between the time periods. For the 96 banks in MSAs with GTA of over $\$ 1$ billion in all the sample years of $1982-2000$, the average GTA virtually doubled from $\$ 10.8$ billion to $\$ 21.8$ billion between the first and second periods. Analogously, for the 193 banks in MSAs with multimarket presence in all the sample years, the mean number of markets rose substantially from 5.20 to 8.78 markets between the two periods. We argue that the changes from below $\$ 1$ billion to above $\$ 1$ billion and from single-market to multimarket that are in our specification are likely to be much more important in terms of competitive pressure on small, single-market banks than are the changes in size or number of markets within the categories of large and multimarket banks. That is, we believe that it makes relatively little difference to a small, singlemarket bank whether a competitor has about \$22 billion versus about $\$ 11$ billion in GTA or is in 5 versus 9 markets because these banks are likely to use similar technologies and compete with small, single-market banks in similar ways. In contrast, the difference between any of these competitors and a typical small, single-market competitor with about $\$ 120$ million in GTA in one market may be quite significant, given the empirical evidence cited above about how small, single-market banks tend to use different technologies and serve different customers from large, multimarket banks.
} 
result noted in many research studies. The consolidation of the banking industry has primarily taken place through M\&As among banks in different local markets.

We control for market demographics by including the natural logs of market population (LN MKT POP) and average per capital personal income (PER CAP INC). In Table 1, we show statistics for both levels and logs for these variables for information purposes, but only the logs are included in the regressions. As shown, average MSA population declines slightly, while per capita income rises between periods.

The state geographic regulations include dummies for the branching restrictions in the state: unit banking (UNIT), limited branching (LIMITED), or statewide branching (STATEWIDE, the excluded base case). We also include a dummy for interstate banking (INTERSTATE). The state regulations were substantially liberalized between the first and second time periods.

We also control for the size and age of the small, single-market bank itself, which could have significant effects on its performance. We include the log of GTA (LN GTA), noting that GTA is constrained to be $\leq \$ 1$ billion. In addition, we specify indicators for whether the bank is in the 6-20 year range (AGE 6-20) or over 20 years old ( $A G E>20)$, with the indicator for the youngest banks ( $A G E \leq 5)$ excluded from the regressions as the base case. As shown, the average size of small, single-market banks increases, but the rise is contained by the constraint on size. Bank age also increases, primarily as a few percentage points of banks moved from under to over 5 years of age.

Finally, all of the regressions include time and bank fixed effects. The number of effects in each period is always one less than the number of years or banks because of the inclusion of intercepts in the regressions. The fixed effects account for average differences across years and across banks that are not captured by the other exogenous variables. These effects also control for average differences across markets that are not covered by the other regressors because each small, single-market bank is also in a unique market. These very strong controls make the hypothesis tests quite stringent because the coefficients on the market shares by bank size and geography only measure the influence of these shares after removing the average differences across markets and time periods.

\section{Empirical results}

\subsection{Full sample ROE regressions}

Table 2 presents the profitability regressions for the full sample of small, single-market banks for both time periods. The first column of coefficients for each time period shows the results when the small, single-market bank 
annual return on equity $(\mathrm{ROE})$ is the dependent variable. In the first period, the coefficients on all three market share categories are positive and significant. A greater presence by large and/or multimarket banks in a typical small, single-market bank's market enhanced that bank's profitability. By contrast, for the second period, the coefficients on the three market shares are all negative and significant. A greater presence by large and/or multimarket banks in a typical small, single-market bank's market decreased that bank's profitability.

As argued above, the key test of the efficiency hypothesis versus the hubris hypothesis is found by examining the differences in the coefficients between the two periods. At the bottom of Table 2, the first column of coefficients shows the differences in the coefficients for the three bank share variables between the two periods and t-tests on these differences. For all three coefficients, the differences are negative and significant at the $1 \%$ level (two-sided). As compared with the 1980s, the 1990s showed a significantly more deleterious effect of the presence of large and/or multimarket banks on the ROE of small, single-market banks. The differences are important economically as well as statistically significant. To illustrate, we multiply the changes in coefficients at the bottom of Table 2 by the actual changes in market shares between the two time periods for the three categories of large and/or multimarket banks using the by-market means shown in Table 1. This yields a change in ROE of 0.0190 or 1.90 percentage points of equity, which represents a loss of $22.90 \%$ relative to the by-market mean ROE of the small, single-market banks in the first period of $0.0832 .^{13}$

Thus, the full sample ROE results are consistent with a dominance of the efficiency hypothesis over the hubris hypothesis - on net, technological progress allowed large, multimarket banks to compete more effectively against small, single-market banks in the 1990s than in the 1980s. This is not to suggest that hubris was not the driving force in much of the consolidation or that all of the large and/or multimarket banks significantly improved their performance due to technological progress, but simply that the efficiency hypothesis dominates empirically.

The finding that the changes in all three market share coefficients between the two periods are negative and significant also suggests that the efficiency hypothesis dominates for both the size and geographic components of the hypothesis. That is, the data are consistent with the hypothesis that technological progress tended to help both large banks and multimarket banks relative to small, single-market banks.

The results may also have a bearing on how community banks might be defined. The finding that the coefficients on the market shares of large, single-market, small, multimarket, and large, multimarket banks are

\footnotetext{
${ }^{13}$ This figure is reached as follows: $[-0.0849 *(-0.0404)-0.0968 * 0.0523-0.0790 * 0.2204]=-0.0190$.
} 
statistically significantly different from zero in both periods also suggests that banks in all three of these categories may use different technologies and compete differently from small, single-market banks. On the assumption that small, single-market banks belong in any definition of community banks, these findings suggest that the definition likely should not include any of the other categories. Thus, the conventional treatment of all small banks as community banks is not consistent with these data.

\subsection{Full sample PROFIT EFF regressions}

The second column of coefficients for each time period at the top of Table 2 show the regression results when PROFIT EFF is the dependent variable in the OLS regressions for the first and second periods. ${ }^{14}$ With respect to the market share variables, the first-period PROFIT EFF regression shows a negative coefficient for the shares of large, single-market banks, but positive and significant coefficients for the shares of small, multimarket and large, multimarket banks. These last two coefficients echo the coefficients for these two categories in the ROE regressions, but the first (negative) coefficient is contrary to the ROE result. For the second time period, all three coefficients are negative (as is true in the ROE regression), and two of them are significant. When we turn to the bottom of Table 2 for the t-tests on the differences in the coefficients between the two periods, we see that the differences are negative for all three categories (as is true for the ROE comparisons) and are significant for the small, multimarket and large, multimarket bank shares, but insignificant for the large, single-market bank shares.

The PROFIT EFF findings are again consistent with a dominance of the efficiency hypothesis over the hubris hypothesis, given the much more negative effect of large, multimarket bank shares on the performance of small, single-market banks in the 1990s than in the 1980s. However, the efficiency hypothesis appears to dominate only for the geographic component of the hypothesis, rather than both the size and geographic components as it did when using the ROE data. The insignificant change in the coefficients for the share for large, single-market banks suggests that the technological change may not have been effective for the size component. Put another way, the PROFIT EFF data are consistent with the possibility that the efficiency improvements between the 1980s and the 1990s were primarily important for banks to operate more effectively in multiple markets across longer distances, rather than for scale per se.

\footnotetext{
${ }^{14}$ Because the PROFIT EFF variable is constructed from annual profit efficiency regressions, its use may introduce the possibility of heteroskedasticity. The same is true of the use of the COST EFF variable discussed below. Standard methods to control for heteroskedasticity in this and all of the other regressions yielded results that were largely unchanged from the results that we report in Tables 2-5.
} 
This slightly different finding from the ROE results may also have implications for the definition for community banks. In effect, the negative, essentially unchanged coefficient in both time periods for large, singlemarket banks suggests that these institutions may have been tough competition for small, single-market banks in both decades. This raises the possibility that these banks may have been providing community banking services more effectively than small, single-market banks all along.

We also investigated further the potential sources of the different finding for the effects of large, singlemarket banks when PROFIT EFF is used as the performance measure in place of ROE. As discussed, PROFIT EFF differs mainly from ROE in that it statistically removes some of the factors over which management likely has little control, at least in the short run. We do this by excluding revenues and costs on fixed netputs, by controlling for the vector of conditions facing the bank $\left[\mathrm{w}^{\mathrm{b}}, \mathrm{y}^{\mathrm{b}}, \mathrm{z}^{\mathrm{b}}, \mathrm{v}^{\mathrm{b}}\right]$ in the profit function $\mathrm{f}(\cdot)$, and by averaging the current, preceding, and following residuals for the same bank and censoring extreme values to reduce random error. We tried removing some of these differences by dropping some of the variables and procedures in estimating PROFIT EFF. We tried dropping from $\mathrm{f}(\cdot)$ the prices of the financial inputs (purchased funds and core deposits), allowing for the possibility of significant market power in setting these prices or that the competitive pressures from large or multimarket banks operate primarily through these prices. We also tried dropping all of the output quantities - the five asset categories specified as variable outputs and off-balance-sheet items (the first fixed netput) - allowing for the possibility that banks can quickly adjust all of these outputs. As well, we tried simultaneously dropping both the two input prices and the six outputs, leaving only controls for the price of labor, the quantities of physical capital and financial equity capital, and the variables for market population and total deposits. We also re-estimated PROFIT EFF by replacing the average of the current, preceding, and following residuals for the bank with the current residual only or with the predicted value from a quadratic trend model using all available observations for that bank. In none of these cases did our findings materially change. ${ }^{15}$

Thus, our empirical support for the empirical dominance of the efficiency hypothesis over the hubris hypothesis remains robust. The different finding for large, single-market banks using PROFIT EFF versus ROE suggests that only the geographic component of the hypothesis is robust, and that large, single-market banks may potentially compete effectively as community banks. However, the source of the different findings for PROFIT

\footnotetext{
${ }^{15}$ As noted, we apply the profit function $\mathrm{f}(\cdot)$ only to data on small, single-market banks, since other banks may produce different products or use different technologies. Nonetheless, we tried estimating PROFIT EFF inclusive of all the other bank categories, and the findings were similar.
} 
EFF remains difficult to determine. Clearly, future research on these issues using alternative data sources and methods is warranted.

\section{3 "Survivor" subsample ROE and PROFIT EFF regressions}

In Table 3, we present regression results that are similar in form to those of Table 2, but in this case we limit our sample in each regression to small, single-market banks that were present for at least five years in the first period and at least five years in the second period. In so doing we are controlling for potential survivorship biases that could arise in the regressions of Table 2. Small, single-market banks that were successful in competing against larger and/or multimarket banks in the first period might grow beyond the $\$ 1$ billion demarcation or begin branching outside their original MSA (or both), thereby disappearing from the sample in the second period and causing the second-period sample to be more heavily weighted with small, single-market banks that were less able to compete against larger and multimarket banks. Successful small, single-market banks might also be acquired by other banks and disappear from the second-period sample. As well, failing banks might disappear, either through FDIC liquidation or through FDICpromoted purchase-and-assumption transactions, yielding a second-period sample that was more heavily weighted with successful small, single-market banks. Consequently, the survivorship bias may on net be either positive or negative.

As shown in Table 3, the market share results for the first and second periods, for both the ROE and the PROFIT EFF regressions, are mostly similar to those of Table 2, albeit with less statistical significance in part due to the loss of more than half the observations. Most important, when we turn to the bottom of Table 3 and the t-tests on the differences in the coefficients on the market shares of large and/or multimarket banks, we find the same pattern as

in Table 2: the differences are negative and significant for all three categories in the ROE regressions, and negative and significant for the small, multimarket and large, multimarket shares in the PROFIT EFF regressions. Thus, our main profitability results are robust - survivorship bias does not appear to explain our findings.

\subsection{Full sample COST/GTA regressions}

In Table 4, we present full sample OLS regressions for the two time periods in which COST/GTA and COST EFF are the dependent variables. Our purpose is to discover whether the profitability performance results occurred primarily through cost effects - which should be reflected in COST/GTA and COST EFF - versus primarily through revenue effects - as would be reflected if the measured cost effects were relatively unimportant.

For the COST/GTA regressions, the predicted signs for the hypotheses are reversed from the profitability regressions, since an increase in costs indicates a worse performance. As shown in Table 4, for the first period the 
effects of market shares of large and/or multimarket banks on small, single-market banks' COST/GTA were mixed: positive but insignificant for large, single-market banks, negative and significant for small, multimarket banks; and positive and significant (at the 10\% level) for large, multimarket banks. In the second period, all three coefficients are positive, and two of the three are significant. At the bottom of Table 4, the differences in coefficients are positive and significant for the share variables representing small, multimarket and large, multimarket banks, but insignificant for the share variables representing large, single-market banks. Thus, the findings reported above for ROE of an empirical dominance of the efficiency hypothesis over the hubris hypothesis appear to be due at least in part to cost effects, but only on the geographic component of the hypothesis. That is, the data are consistent with the hypothesis that technologically-based improvements in the abilities of both small and large multimarket banks to compete more effectively in the second period may have encouraged small, single-market banks to respond in ways that involved higher costs - such as higher deposit rates or greater expenses on advertising or quality improvements - to try to retain customers.

We compute the economic magnitudes of the cost effects and compare them to the profitability effects above to determine whether the profitability effects occurred primarily through revenues versus costs. We multiply the changes in coefficients at the bottom of Table 4 by the actual changes in the three market shares between the two time periods (again using the by-market means), which yields a change of +0.0006 in COST/GTA. To compare this with the ROE result above (which has bank equity as the denominator), we convert the COST/GTA result to an equity base. We divide the +0.0006 change in COST/GTA by 0.0833 , the average (by market) equity/GTA ratio for small, single-market banks in the first time period (not shown in Table 1). This yields a change of +0.0069 in COST/equity. By contrast, the change in ROE reported above was -0.0190 . Thus, the increases in costs account for about one-third of the reduction in profitability. The evidence suggests that most of the effects of the efficiency hypothesis on the performance of small, single-market banks occur through reduced revenues, although some of the losses also appear to occur through increased costs.

\subsection{Full sample COST EFF regressions}

For the COST EFF regressions in Table 4, the predicted signs for the hypothesis are the same as in the profitability regressions, since an increase in COST EFF indicates improved performance. The coefficients on the market shares of large and/or multimarket banks are uniformly positive over both time periods and are significant for four of the six possibilities, suggesting that competition from these other banks tended to improve the cost efficiency of small, multimarket banks in both the 1980s and 1990s. 
The t-tests on the differences in the coefficients between the two periods at the bottom of Table 4, reveal that two of the three differences are negative and significant, and the other is positive, but insignificant. The negative, significant effects are for the two large bank size categories. The data are consistent with dominance of the efficiency hypothesis over the hubris hypothesis in terms of cost performance, at least for large banks. Thus, both the COST/GTA and COST EFF findings are consistent with a dominance of the efficiency hypothesis for large, multimarket banks, although they are not consistent on whether it is size or geographic component of the hypothesis that is driving the result.

\section{6 "Survivor" subsample COST/GTA and COST EFF regressions}

As was true for the ROE and PROFIT EFF regressions, we also ran the COST/GTA and COST EFF regressions over a smaller sample that included only small, single-market banks that were present for at least five years in the first period and at least five years in the second period, so as to control for potential survivorship bias. The results in Table 5 are broadly consistent with those of Table 4, although there are again some differences in statistical significance.

\subsection{Modifying the time periods}

As a robustness check, we tried changing the cutoff date between the two periods. We re-ran the entire analysis after moving the observations for 1990 into the second time period. Our two time periods became 1982-1989 and 1990-2000. This made the sample sizes for the two time periods closer to equal and moved the worst year for overall profitability performance for small, single-market banks from the first period to the second period. ${ }^{16}$

Our results with this modification generally remain as we have reported above. For our main results the full-sample profitability regressions of Table 2 - the signs and significance levels of the differences in coefficients that are reported at the bottom of that table remain unchanged. For the remaining results that are reported in Tables 3-5, the signs on the differences in coefficients reported at the bottom of those tables remain unchanged, although significance levels decrease in some instances (especially for the survivor subsamples).

\subsection{Coefficients on Control Variables}

We turn briefly to the coefficients on the control variables, focusing on the ROE regressions in Table 2 . The coefficient on HERF is insignificant in the first period, but has the expected positive and significant effect in the second period. The insignificant effect of the first period may not be due to the inclusion of the market share variables,

\footnotetext{
${ }^{16}$ This worst performance may be seen in Table 2, where the coefficients on the YEAR 1990 dummy variable is the most negative for both ROE and PROFIT EFF.
} 
which have strong effects on performance and are correlated with market concentration..

The negative and significant coefficient on LN MKT POP suggests that small, single-market banks perform better in smaller metropolitan markets, which may reflect a greater importance of relationships and soft information in smaller markets. In the second period, the coefficient is statistically insignificant, which may reflect in part the diminishment of the comparative advantage of small, single-market banks in small markets as other banks were able to compete more effectively in these markets under the efficiency hypothesis.

The positive and significant coefficient on LN PER CAP INC in the first period indicates that small, single-market banks were more profitable in areas with higher incomes, as expected. The negative coefficient in the second period is contrary to expectations, but its absolute size is an order of magnitude smaller than the coefficient in the first period.

The coefficients on state geographic regulations have mixed and changing signs over time. These findings may reflect the conflicting effects of these regulations on any one category of banks. Restrictions on competition may generally positively affect industry performance, but may also help some types of banks compete more effectively against others.

The coefficient on LN GTA is negative and significant in the first period, but essentially zero in second period. Similar to the arguments above regarding LN MKT POP, the LN GTA findings are consistent with hypothesis that the smallest of the small, single-market banks may have had comparative advantages in the 1980s, but these advantages were overcome by technological changes by the 1990s. Here, the argument is that there may have been differential effects within the category of small, single-market banks, rather than between these banks and other categories as discussed and tested in this paper.

The positive and significant coefficients on AGE 6-20 and AGE $>20$ indicate that small, single-market banks that were seasoned (i.e., more than five years old) tended to be more profitable than start-up and very young small, single-market banks. These coefficients remained positive and significant and with similar magnitudes in the second period. These results are consistent with earlier research on the relative profitability of older and younger banks (DeYoung and Hasan 1998).

The coefficients on the annual dummy variables are consistent with banking industry performance over time - declining profitability commercial banking during the 1980s into the beginning of the 1990s, then generally increasing profitability through 2000 . The coefficients on the bank fixed-effects dummies are not shown, but they are in statistically significant in aggregate in both time periods. 


\section{Conclusion}

We offer and test two competing hypotheses for the consolidation trend in banking, which may also apply to some extent elsewhere in retailing. Under the efficiency hypothesis, technological progress improved the performance of large, multimarket firms relative to small, single-market firms, whereas under the $\underline{\text { hubris }}$ hypothesis, consolidation was largely driven by corporate hubris with a sacrifice of some firm performance. The main testable predictions distinguishing these hypotheses concern the change over time in the effect of competition from large, multimarket firms on the performance of small, single-market firms in the same markets. Under the efficiency hypothesis, a greater market share for large, multimarket firms exerted more competitive pressure and had more deleterious effects on the performance of their small, single-market rivals in a later period of time than in an earlier period. The hubris hypothesis predicts the opposite effect - less competitive pressure over time from large, multimarket banks on the performance of small, single-market banks.

We test these predictions using U.S. banking industry data over the period 1982-2000. We include measures of the annual performance of all small, single-market banks in U.S. metropolitan markets and the local shares in these markets of large, multimarket banks and banks with other combinations of size and geographic spread. We divide the data set into two time periods of 1982-1990 and 1991-2000 based on the extant research on the effects of technological progress on the banking industry. The key test is for changes between these two time periods in the effects of the market shares of large and/or multimarket banks on the performance of small, single-market banks.

Our results are highly consistent with an empirical dominance of the efficiency hypothesis over the hubris hypothesis - that on net, technological progress allowed large, multimarket banks to compete more effectively against small, single-market banks in the 1990s than in the 1980s. The hubris hypothesis is not ruled out - our finding is only a net effect that the efficiency hypothesis appears to be stronger empirically. The result is both economically and statistically significant. This main finding is also robust to 1) the use of profitability versus cost measures of performance, 2) the specification of conventional accounting measures of performance versus frontier efficiency estimates; 3) changing how the efficiency measures are estimated; 4) accounting for survivorship bias by including only banks that were in both time periods for at least 5 years; and 5) altering the year of cutoff between the two time periods.

Our analysis yields several additional findings of interest. The efficiency and hubris hypotheses are separable in terms of the size (small versus large) and geographic (single-market versus multimarket) 
components. Our separate specification of the effects of market shares of large, single-market banks and small, multimarket banks as well as large, multimarket banks allows us to test these components separately. The findings in favor of the efficiency hypothesis are more consistent for the geographic component than for the size component. That is, virtually all of our findings are consistent with the hypothesis that technological progress helped large, multimarket banks compete more effectively against small, single-market banks, but in some cases, the findings did not extend to large banks that remain in a single market. This suggests the possibility that the efficiency improvements in banking may have been primarily important for banks to expand geographically, rather than increasing scale per se, but more research would be needed for definitive evidence on this point.

The use of both profitability and cost indicators also allow us to investigate the extent to which the effects of the hypotheses on performance are manifested primarily through revenues versus costs. The findings suggest that the efficiency hypothesis primarily reduces the performance of small, single-market banks through reduced revenues (e.g., possibly lower loan rates, fees), although some losses also occur through higher costs (e.g., possibly higher deposit rates, additional advertising/quality expenses).

Finally, our findings may provide information on some of the important research and issues related to community banking. On the assumption that small, single-market banks typically qualify as community banks institutions that specialize in relationship services to local communities based on soft, local information - the strong findings in favor of the efficiency hypothesis clearly suggest such institutions have lost some of their comparative advantage over time.

Our findings also give some evidence on how community banks might be defined empirically. Most of the findings suggest that conventional definition in which all small banks (typically those with under $\$ 1$ billion in assets) are counted as community banks - regardless of their geographic dispersion - may not be a good choice. The findings clearly suggest that small, multimarket banks compete differently from small, single-market banks. The findings are less clear regarding whether large, single-market banks might be included in a working definition of community banks. Some of the findings suggest that these institutions may have competed successfully in providing similar services to small, single-market banks with little change between the decades. More research would be needed to confirm these findings. 


\section{$\underline{\text { References }}$}

Akhavein, Jalal D., Allen N. Berger, and David B. Humphrey. 1997. "The Effects of Bank Megamergers on Efficiency and Prices: Evidence from the Profit Function.” Review of Industrial Organization 12: 95-139.

Akhavein, Jalal, W. Scott Frame, and Lawrence J. White. 2005. "The Diffusion of Financial Innovations: An Examination of the Adoption of Small Business Credit Scoring by Large Banking Organizations." Journal of Business 78.

Avery, Robert B., and Katherine A. Samolyk. 2004. "Bank Consolidation and the Provision of Banking Services: Small Commercial Loans," Journal of Financial Services Research 25: 291-325.

Amel, Dean F., and Martha Starr-McCluer. 2002. "Market Definition in Banking: Recent Evidence." Antitrust Bulletin 47: 63-89.

Bauer, Paul W., and Gary D. Ferrier. 1996. "Efficiency Measurement Issues for Payments Processing.” Journal of Money, Credit and Banking 28: 1004-1039.

Berger, Allen N. 2003. "The Economic Effects of Technological Progress: Evidence from the Banking Industry." Journal of Money, Credit, and Banking 35: 141-176.

Berger, Allen N., Seth D. Bonime, Lawrence G. Goldberg, and Lawrence J. White. 2004. "The Dynamics of Market Entry: The Effects of Mergers and Acquisitions on Entry in the Banking Industry." Journal of Business 77: 797-834.

Berger, Allen N., and Robert DeYoung. 2001. "The Effects of Geographic Expansion on Bank Efficiency.” Journal of Financial Services Research 19: 163-184.

Berger, Allen N., and Robert DeYoung. forthcoming. "Technological Progress and the Geographic Expansion of the Banking Industry." Journal of Money, Credit, and Banking.

Berger, Allen N., W. Scott Frame, and Nathan H. Miller. 2005. "Credit scoring and the availability, price, and risk of small business credit." Journal of Money, Credit, and Banking 37.

Berger, Allen N., Lawrence G. Goldberg, and Lawrence J. White. 2001. "The Effects of Dynamic Changes in Bank Competition on the Supply of Small Business Credit," European Finance Review 5: 115-139.

Berger, A.N., Hanweck, G.A., Humphrey, D.B., 1987. "Competitive viability in banking: Scale, scope, and product mix economies," Journal of Monetary Economics 20: 501-520.

Berger, A.N., Humphrey, D.B., 1992. "Megamergers in banking and the use of cost efficiency as an antitrust defense." Antitrust Bulletin 37: 541-600.

Berger, A.N., Mester, L.J., 1997. "Inside the black box: What explains differences in the efficiencies of financial institutions?" Journal of Banking and Finance 21: 895-947.

Berger, A.N., Mester, L.J., 2003. "Explaining the dramatic changes in the performance of U.S. Banks: Technological change, deregulation, and dynamic changes in competition." Journal of Financial Intermediation 12: 57-95.

Berger, Allen N., Nathan H. Miller, Mitchell A. Petersen, Raghuram G. Rajan, and Jeremy C. Stein. forthcoming. "Does Function Follow Organizational Form? Evidence From the Lending Practices of Large and Small 


\section{Banks." Journal of Financial Economics.}

Berger, Allen N., Richard J. Rosen, and Gregory F. Udell, 2005. "Does Market Size Structure Affect Competition? The Case of Small Business Lending." Board of Governors of the Federal Reserve System working paper.

Berger, A.N., Saunders, A., Scalise, J.M., Udell, G.F., 1998. "The effects of bank mergers and acquisitions on small business lending." Journal of Financial Economics 50: 187-229.

Berger, Allen N., and Gregory F. Udell. 2002. "Small Business Credit Availability and Relationship Lending: The Importance of Bank Organisational Structure.” Economic Journal 112: F32-F53.

Cole, Rebel A., Lawrence G. Goldberg, and Lawrence J. White. 2004. "Cookie-cutter versus character: The Micro Structure of Small Business Lending by Large and Small Banks." Journal of Financial and Quantitative Analysis 39: 227-251.

Courchane, Marsha, David Nickerson, and Richard Sullivan. 2002. "Investment in Internet Banking as a Real Option: Theory and Tests," Journal of Multinational Financial Management 12: 347-63.

Demsetz, Rebecca S., and Phillip E. Strahan. 1997. "Diversification, Size, and Risk at Bank Holding Companies." Journal of Money, Credit, and Banking 29: 300-13.

DeYoung, Robert, and Iftekhar Hasan. 1998. "The Performance of De Novo Commercial Banks: A Profit Efficiency Approach.” Journal of Banking and Finance 22, 565-587.

DeYoung, Robert, William C. Hunter, and Gregory F. Udell. 2004. "The Past, Present, and Probable Future for Community Banks.” Journal of Financial Services Research 25: 85-133.

DiSalvo, James. 2002. "Deposit runoff from bank mergers.” Federal Reserve Bank of Philadelphia working paper.

Frame, W.S., Srinivasan, A., Woosley, L., 2001, The effect of credit scoring on small business lending, Journal of Money, Credit, and Banking, 33: 813-825.

Frame, W. Scott, Michael Padhi, and Lynn Woolsey. 2004. "Credit Scoring and the Availability of Small Business Credit in Low- and Moderate Income Areas.” Financial Review 39: 34-54.

Furst, Karen, William W. Lang, and Daniel E. Nolle. 2002. "Internet Banking.” Journal of Financial Services Research 22: 95-117.

Hancock, Diana, David B. Humphrey, and James A. Wilcox. 1999. "Cost Reductions in Electronic Payments: The Roles of Consolidation, Economies of Scale, and Technical Change.” Journal of Banking and Finance 23: 391-421.

Hannan, Timothy H. 2003. "Changes in Non-Local Lending to Small Business.” Journal of Financial Services Research 24: 31-46.

Hannan, Timothy H., and Robin A. Prager. 2004. "The Competitive Implications of Multimarket Bank Branching." Journal of Banking and Finance 28: 1989-1914.

Heitfield, Erik A. 1999. "What do Interest Rate Data Say about the Geography of Retail Banking Markets?" Antitrust Bulletin 44: 333-47. 
Heitfield, Erik, and Robin A. Prager. 2004. "The Geographic Scope of Retail Deposit Markets." Journal of Financial Services Research 25: 37-55.

Hughes, Joseph P., William Lang, and Loretta J. Mester, and Choon-Geol Moon. 1996. "Efficient Banking Under Interstate Branching.” Journal of Money, Credit, and Banking 28: 1043-1071.

Hughes, J.P., Lang, W.W., Mester, L.J., Moon, C., 1999. “The dollars and sense of bank consolidation.” Journal of Banking and Finance 23: 291-324.

Park, Kwangwoo, and George Pennacchi. 2004. "Harming depositors and helping borrowers: The disparate impact of bank consolidation." University of Illinois working paper.

Petersen, Mitchell A., and Raghuram G. Rajan. 2002. "Does distance still matter? The information revolution in small business lending." Journal of Finance 57: 2533-70.

Radecki, Lawrence J. 1998. “The Expanding Geographic Reach of Retail Banking Markets.” Federal Reserve Bank of New York Economic Policy Review 4: 15-34.

Rhoades, S.A., 1998. "The efficiency effects of bank mergers: An overview of case studies of nine mergers." Journal of Banking and Finance 22: 273-291.

Roll, Richard. 1986. “The Hubris Hypothesis of Corporate Takeovers.” Journal of Business 59: 197-216.

Stein, Jeremy C. 2002. "Information Production and Capital Allocation: Decentralized vs. Hierarchical Firms," Journal of Finance 57, 1891-1921.

Williamson, O., “Corporate Finance and Corporate Governance,” Journal of Finance 43 (1988), 567-591. 
Table 1. Definitions and selected summary statistics for variables used in the performance regressions for small, singlemarket banks. The data are annual observations for banks with gross total assets (GTA) $\leq \$ 1$ billion that operate in a single Metropolitan Statistical Area (MSA) for the first time period (1982 - 1990) and second time period (1991 - 2000). Summary statistics are shown by bank and by market for both time periods. Statistics by bank are based on one observation per small, single-market bank per year, and represent the samples used in the regressions. Statistics by market are based on one observation per market per year for all MSAs with at least one small, single-market bank. Each by-market observation for the variables based on markets (e.g., SHARE LRG, MULT) is the unique value for that variable for the market and year, and each observation for the variables based on banks (e.g., ROE) is the average for all small, single-market banks for the market and year. Statistics by market may more accurately represent the market-based variables, given that all markets are weighted equally for each year, as opposed to the statistics by bank, which give greater weight to markets with more small, singlemarket banks in those years. The exogenous variables include market shares by bank size and geography, local market concentration, market demographics, state geographic regulations, bank size and age, and time and bank fixed effects. All exogenous variables (other than time effects) are lagged by one year relative to the dependent variables to reduce potential endogeneity problems. All financial variables are in real 1994 dollars, deflated using the CPI. Abbreviations K, M, B denote values in thousands, millions, and billions, respectively. Main data sources: Call Reports for bank balance sheet and income items; FDIC Summary of Deposits for the locations of bank offices and deposits.

\begin{tabular}{|c|c|c|c|c|c|c|c|c|c|}
\hline & & \multicolumn{4}{|c|}{$\begin{array}{l}\text { First Time Period } \\
(1982-1990)\end{array}$} & \multicolumn{4}{|c|}{$\begin{array}{c}\text { Second Time Period } \\
(1991-2000)\end{array}$} \\
\hline & & \multicolumn{2}{|c|}{$\begin{array}{l}\text { By Bank } \\
(\mathrm{N}=42,855)\end{array}$} & \multicolumn{2}{|c|}{$\begin{array}{l}\text { By Market } \\
(\mathrm{N}=2,703)\end{array}$} & \multicolumn{2}{|c|}{$\begin{array}{c}\text { By Bank } \\
(\mathrm{N}=27,175)\end{array}$} & \multicolumn{2}{|c|}{$\begin{array}{l}\text { By Market } \\
(\mathrm{N}=2,834)\end{array}$} \\
\hline & & Mean & $\begin{array}{l}\text { Min, } \\
\text { Max }\end{array}$ & Mean & $\begin{array}{l}\text { Min, } \\
\text { Max }\end{array}$ & Mean & $\begin{array}{l}\text { Min, } \\
\text { Max }\end{array}$ & Mean & $\begin{array}{l}\text { Min, } \\
\text { Max }\end{array}$ \\
\hline \multicolumn{10}{|c|}{ DEPENDENT VARIABLES } \\
\hline \multicolumn{10}{|c|}{ Performance of Small, Single-Market Banks } \\
\hline ROE & $\begin{array}{l}\text { Return on equity for small, single- } \\
\text { market banks (obs. outside the interval } \\
{[-1.0,0.50] \text { excluded). }}\end{array}$ & 0.0789 & $\begin{array}{r}-0.9981 \\
0.4989\end{array}$ & 0.0832 & $\begin{array}{c}-0.8023 \\
0.2234\end{array}$ & 0.1062 & $\begin{array}{l}-1.00 \\
0.4922\end{array}$ & 0.1059 & $\begin{array}{r}-0.8187 \\
0.3901\end{array}$ \\
\hline PROFIT EFF & $\begin{array}{l}\text { Ratio of bank's predicted variable } \\
\text { profits to predicted best-practice } \\
\text { variable profits for the same conditions } \\
\text { (obs. with predicted variable profits } \\
\text { outside the interval [-equity, equity] or } \\
\text { predicted best-practice variable profits } \\
<5 \% \text { of equity excluded). }\end{array}$ & 0.6238 & $\begin{array}{c}-5.683 \\
1.00\end{array}$ & 0.6389 & $\begin{array}{c}-1.301 \\
1.00\end{array}$ & 0.6630 & $\begin{array}{c}-5.344 \\
1.00\end{array}$ & 0.6645 & $\begin{array}{l}-0.932 \\
1.00\end{array}$ \\
\hline COST/GTA & $\begin{array}{l}\text { Total interest plus noninterest expenses } \\
\text { divided by gross total assets (GTA). } \\
\text { (obs. outside }[0.02,0.20] \text { excluded) }\end{array}$ & 0.0649 & $\begin{array}{c}0.0202 \\
0.1984\end{array}$ & 0.0652 & $\begin{array}{c}0.0381 \\
0.0972\end{array}$ & 0.0435 & $\begin{array}{r}0.0200, \\
0.1978\end{array}$ & 0.0436 & $\begin{array}{l}0.0261 \\
0.0812\end{array}$ \\
\hline COST EFF & $\begin{array}{l}\text { Ratio of bank's predicted best-practice } \\
\text { variable costs to predicted variable } \\
\text { costs for the same conditions (obs. } \\
\text { with predicted best-practice variable } \\
\text { costs }<2 \% \text { of GTA or predicted } \\
\text { variable costs }>\text { GTA excluded). }\end{array}$ & 0.8157 & $\begin{array}{c}0.2519 \\
1.00\end{array}$ & 0.8247 & $\begin{array}{c}0.5202 \\
1.00\end{array}$ & 0.7878 & $\begin{array}{c}0.1962 \\
1.00\end{array}$ & 0.7885 & $\begin{array}{l}0.4282 \\
1.00\end{array}$ \\
\hline
\end{tabular}




\begin{tabular}{|c|c|c|c|c|c|c|c|c|c|}
\hline \multicolumn{10}{|l|}{ EXOGENOUS VARIABLES } \\
\hline \multicolumn{10}{|c|}{ Market Shares by Bank Size and Geography } \\
\hline $\begin{array}{l}\text { SHARE SML, SING } \\
\text { (omitted as base case) }\end{array}$ & $\begin{array}{l}\text { Share of the market's total deposits } \\
\text { held by small }(\mathrm{GTA} \leq \$ 1 \mathrm{~B}) \text {, single- } \\
\text { market banks. }\end{array}$ & 0.5598 & $\begin{array}{l}0.0018 \\
1.00\end{array}$ & 0.5096 & $\begin{array}{l}0.0018 \\
1.00\end{array}$ & 0.3267 & $\begin{array}{l}0.0012 \\
1.00\end{array}$ & 0.2773 & $\begin{array}{l}0.0012 \\
1.00\end{array}$ \\
\hline SHARE LRG, SING & $\begin{array}{l}\text { Share of the market's total deposits } \\
\text { held by large }(\mathrm{GTA}>\$ 1 \mathrm{~B}) \text {, single- } \\
\text { market banks. }\end{array}$ & 0.2159 & $\begin{array}{c}0.00 \\
0.8357\end{array}$ & 0.0733 & $\begin{array}{c}0.00 \\
0.8357\end{array}$ & 0.1077 & $\begin{array}{c}0.00 \\
0.7898\end{array}$ & 0.0329 & $\begin{array}{c}0.00 \\
0.7898\end{array}$ \\
\hline SHARE SML, MULT & $\begin{array}{l}\text { Share of the market's total deposits } \\
\text { held by small, multimarket banks. }\end{array}$ & 0.0426 & $\begin{array}{c}0.00 \\
0.9585\end{array}$ & 0.1022 & $\begin{array}{c}0.00 \\
0.9585\end{array}$ & 0.0997 & $\begin{array}{c}0.00 \\
0.9291\end{array}$ & 0.1545 & $\begin{array}{c}0.00 \\
0.9291\end{array}$ \\
\hline SHARE LRG, MULT & $\begin{array}{l}\text { Share of the market's total deposits } \\
\text { held by large, multimarket banks. }\end{array}$ & 0.1817 & $\begin{array}{c}0.00 \\
0.9875\end{array}$ & 0.3149 & $\begin{array}{c}0.00 \\
0.9875\end{array}$ & 0.4659 & $\begin{array}{c}0.00 \\
0.9836\end{array}$ & 0.5353 & $\begin{array}{c}0.00 \\
0.9836\end{array}$ \\
\hline \multicolumn{10}{|l|}{ Market Concentration } \\
\hline HERF & $\begin{array}{l}\text { Herfindahl index based on all banks' } \\
\text { deposit shares. }\end{array}$ & 0.1438 & $\begin{array}{l}0.0426 \\
0.5574\end{array}$ & 0.1935 & $\begin{array}{l}0.0426 \\
0.5574\end{array}$ & 0.1552 & $\begin{array}{l}0.0500 \\
0.8215\end{array}$ & 0.1935 & $\begin{array}{c}0.0500 \\
0.8215\end{array}$ \\
\hline \multicolumn{10}{|l|}{ Market Demographics } \\
\hline $\begin{array}{l}\text { MKT POP } \\
\text { (omitted in favor of } \\
\text { log form) }\end{array}$ & Market population. & $2.069 \mathrm{M}$ & $\begin{array}{l}66.00 \mathrm{~K} \\
8.88 \mathrm{M}\end{array}$ & $0.783 \mathrm{M}$ & $\begin{array}{l}66.00 \mathrm{~K} \\
8.88 \mathrm{M}\end{array}$ & $1.796 \mathrm{M}$ & $\begin{array}{c}53.09 \mathrm{~K}, \\
9.55 \mathrm{M}\end{array}$ & $0.677 \mathrm{M}$ & $\begin{array}{c}53.09 \mathrm{~K} \\
9.55 \mathrm{M}\end{array}$ \\
\hline LN MKT POP & Natural log of market population. & 13.84 & $\begin{array}{l}11.10 \\
16.00\end{array}$ & 12.95 & $\begin{array}{l}11.10 \\
16.00\end{array}$ & 13.69 & $\begin{array}{l}10.88 \\
16.07\end{array}$ & 12.79 & $\begin{array}{l}10.88 \\
16.07\end{array}$ \\
\hline $\begin{array}{l}\text { PER CAP INC } \\
\text { (omitted in favor of } \\
\text { log form) }\end{array}$ & $\begin{array}{l}\text { Average annual personal income in a } \\
\text { market (in real } 1994 \text { dollars). }\end{array}$ & $19.62 \mathrm{~K}$ & $\begin{array}{l}8.498 \mathrm{~K} \\
38.27 \mathrm{~K}\end{array}$ & $18.41 \mathrm{~K}$ & $\begin{array}{l}8.50 \mathrm{~K} \\
38.27 \mathrm{~K}\end{array}$ & $23.26 \mathrm{~K}$ & $\begin{array}{l}10.29 \mathrm{~K} \\
50.00 \mathrm{~K}\end{array}$ & $21.78 \mathrm{~K}$ & $\begin{array}{l}10.29 \mathrm{~K} \\
50.00 \mathrm{~K}\end{array}$ \\
\hline LN PER CAP INC & $\begin{array}{l}\text { Natural log of the average annual } \\
\text { personal income in a market. }\end{array}$ & 2.961 & $\begin{array}{l}2.140 \\
3.645\end{array}$ & 2.896 & $\begin{array}{l}2.140 \\
3.645\end{array}$ & 3.130 & $\begin{array}{l}2.331 \\
3.912\end{array}$ & 3.063 & $\begin{array}{l}2.331 \\
3.912\end{array}$ \\
\hline \multicolumn{10}{|c|}{ State Geographic Regulations } \\
\hline UNIT & Dummy indicating unit banking state. & 0.2435 & $\begin{array}{l}0.00 \\
1.00\end{array}$ & 0.1154 & $\begin{array}{l}0.00 \\
1.00\end{array}$ & 0.0074 & $\begin{array}{l}0.00 \\
1.00\end{array}$ & 0.0021 & $\begin{array}{l}0.00 \\
1.00\end{array}$ \\
\hline LIMIT & $\begin{array}{l}\text { Dummy indicating limited branching } \\
\text { state. }\end{array}$ & 0.5863 & $\begin{array}{l}0.00 \\
1.00\end{array}$ & 0.5993 & $\begin{array}{l}0.00 \\
1.00\end{array}$ & 0.2513 & $\begin{array}{l}0.00 \\
1.00\end{array}$ & 0.1556 & $\begin{array}{l}0.00 \\
1.00\end{array}$ \\
\hline $\begin{array}{l}\text { STATEWIDE } \\
\text { (omitted as base case) }\end{array}$ & $\begin{array}{l}\text { Dummy indicating unlimited } \\
\text { branching within state. }\end{array}$ & 0.1702 & $\begin{array}{l}0.00 \\
1.00\end{array}$ & 0.2852 & $\begin{array}{l}0.00 \\
1.00\end{array}$ & 0.7412 & $\begin{array}{l}0.00 \\
1.00\end{array}$ & 0.8423 & $\begin{array}{l}0.00 \\
1.00\end{array}$ \\
\hline INTERSTATE & $\begin{array}{l}\text { Dummy indicating interstate bank } \\
\text { holding company expansion is } \\
\text { allowed. }\end{array}$ & 0.3248 & $\begin{array}{l}0.00 \\
1.00\end{array}$ & 0.3984 & $\begin{array}{l}0.00 \\
1.00\end{array}$ & 0.9670 & $\begin{array}{l}0.00 \\
1.00\end{array}$ & 0.9795 & $\begin{array}{l}0.00 \\
1.00\end{array}$ \\
\hline \multicolumn{10}{|l|}{ Bank Size and Age } \\
\hline $\begin{array}{l}\text { GTA } \\
\text { (omitted in favor } \\
\text { of log form) }\end{array}$ & $\begin{array}{l}\text { Bank's gross total assets (in real } 1994 \\
\text { dollars) for small, single-market banks. }\end{array}$ & $117.1 \mathrm{M}$ & $\begin{array}{l}426.7 \mathrm{~K} \\
999.4 \mathrm{M}\end{array}$ & $128.2 \mathrm{M}$ & $\begin{array}{c}6.4 \mathrm{M} \\
551.2 \mathrm{M}\end{array}$ & $127.4 \mathrm{M}$ & $\begin{array}{c}2.6 \mathrm{M} \\
999.9 \mathrm{M}\end{array}$ & $130.9 \mathrm{M}$ & $\begin{array}{l}11.2 \mathrm{M} \\
973.5 \mathrm{M}\end{array}$ \\
\hline
\end{tabular}




\begin{tabular}{|c|c|c|c|c|c|c|c|c|c|}
\hline LN GTA & $\begin{array}{l}\text { Natural log of bank gross total assets } \\
\text { (in thousands). }\end{array}$ & 11.09 & $\begin{array}{l}7.185 \\
13.81\end{array}$ & 11.15 & $\begin{array}{l}8.639 \\
13.17\end{array}$ & 11.23 & $\begin{array}{l}7.895 \\
13.81\end{array}$ & 11.26 & $\begin{array}{l}8.36 \\
13.79\end{array}$ \\
\hline $\begin{array}{l}\text { AGE } \\
\text { (omitted in favor of } \\
\text { categorical dummies) }\end{array}$ & $\begin{array}{l}\text { Number of calendar years since the } \\
\text { bank was chartered (integer). }\end{array}$ & 43.98 & $\begin{array}{l}1.00 \\
190.0\end{array}$ & 48.44 & $\begin{array}{l}1.00 \\
142.0\end{array}$ & 47.03 & $\begin{array}{l}1.00 \\
196.0\end{array}$ & 48.41 & $\begin{array}{l}1.00 \\
156.0\end{array}$ \\
\hline $\begin{array}{l}\mathrm{AGE} \leq 5 \\
\text { (omitted as base case) }\end{array}$ & $\begin{array}{l}\text { Dummy indicating bank's age } \leq 5 \\
\text { years. }\end{array}$ & 0.1559 & $\begin{array}{l}0.00 \\
1.00\end{array}$ & 0.1546 & $\begin{array}{l}0.00 \\
1.00\end{array}$ & 0.1183 & $\begin{array}{l}0.00 \\
1.00\end{array}$ & 0.1334 & $\begin{array}{l}0.00, \\
1.00\end{array}$ \\
\hline AGE 6-20 & $\begin{array}{l}\text { Dummy indicating bank's age } 6-20 \\
\text { years, inclusive. }\end{array}$ & 0.2434 & $\begin{array}{l}0.00 \\
1.00\end{array}$ & 0.2235 & $\begin{array}{l}0.00 \\
1.00\end{array}$ & 0.2754 & $\begin{array}{l}0.00 \\
1.00\end{array}$ & 0.2676 & $\begin{array}{l}0.00 \\
1.00\end{array}$ \\
\hline $\mathrm{AGE}>20$ & $\begin{array}{l}\text { Dummy indicating bank's age is }>20 \\
\text { years. }\end{array}$ & 0.6008 & $\begin{array}{l}0.00 \\
1.00\end{array}$ & 0.6219 & $\begin{array}{l}0.00 \\
1.00\end{array}$ & 0.6063 & $\begin{array}{l}0.00 \\
1.00\end{array}$ & 0.5990 & $\begin{array}{l}0.00 \\
1.00\end{array}$ \\
\hline \multicolumn{10}{|l|}{ Fixed Effects } \\
\hline TIME EFFECTS & $\begin{array}{l}8 \text { effects for first time period; } \\
9 \text { effects for second time period. }\end{array}$ & - & - & - & - & - & - & - & - \\
\hline BANK EFFECTS & $\begin{array}{l}6690 \text { effects for first time period; } \\
4416 \text { effects for second time period. }\end{array}$ & - & - & - & - & - & - & - & - \\
\hline
\end{tabular}


Table 2. OLS estimates from ROE and Profit Efficiency performance regressions using the full sample of small, singlemarket banks. Data sets are unbalanced panels, 1982-2000. Superscripts *,**, and *** indicate significant difference from zero at $10 \%, 5 \%$, and 1\% levels, two-sided. Bank fixed effects coefficients are not reported (only the F-stats for all bank effects together are shown).

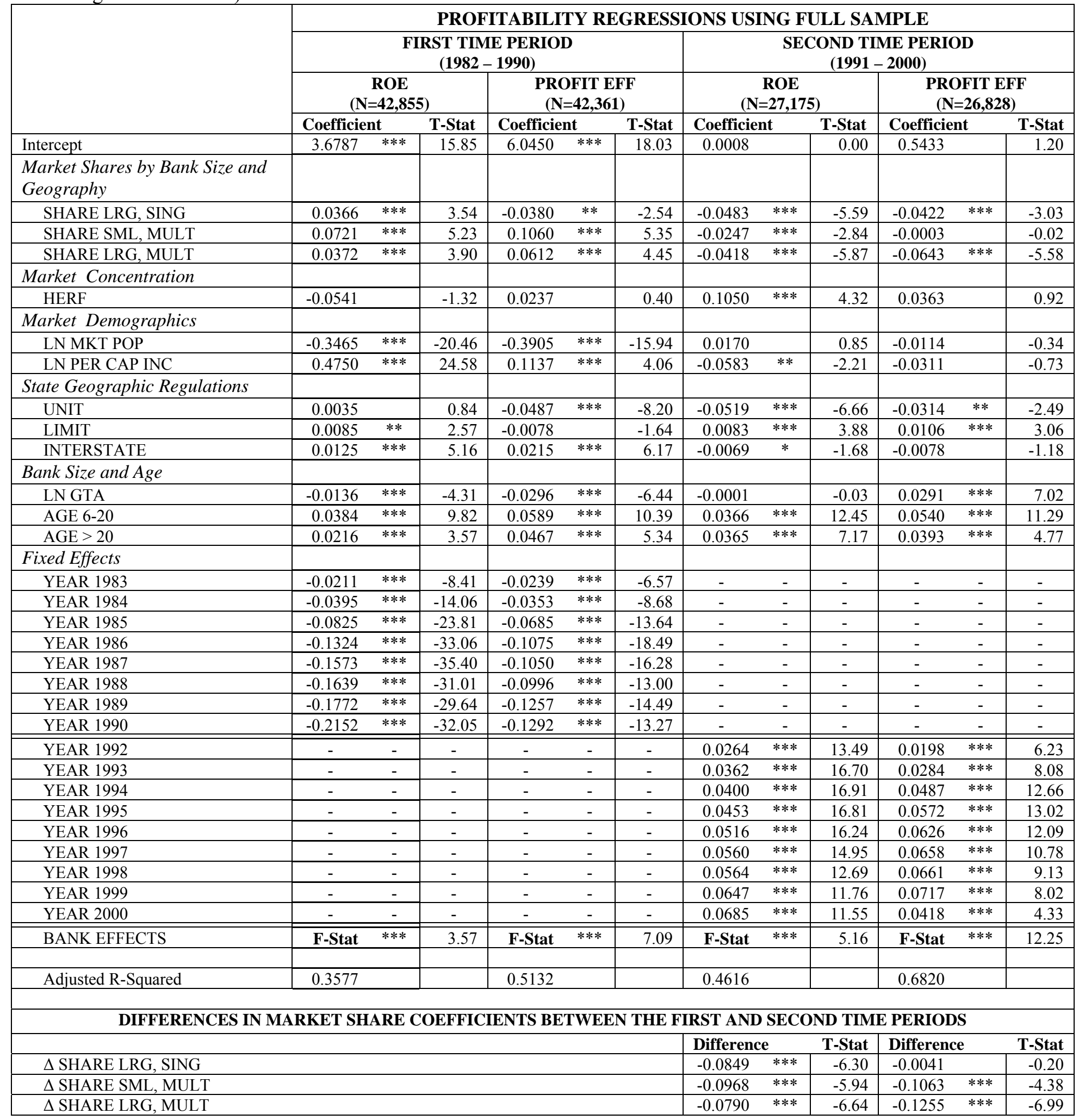


Table 3. OLS estimates from ROE and Profit Efficiency performance regressions using the "survivor" subsample of small, single-market banks that only includes banks present in at least 5 years of each time period. Data sets are unbalanced panels, 1982-2000. Superscripts *,**, and *** indicate significant difference from zero at 10\%, 5\%, and $1 \%$ levels, twosided. Bank fixed effects coefficients are not reported (only the F-stats for all bank effects together are shown).

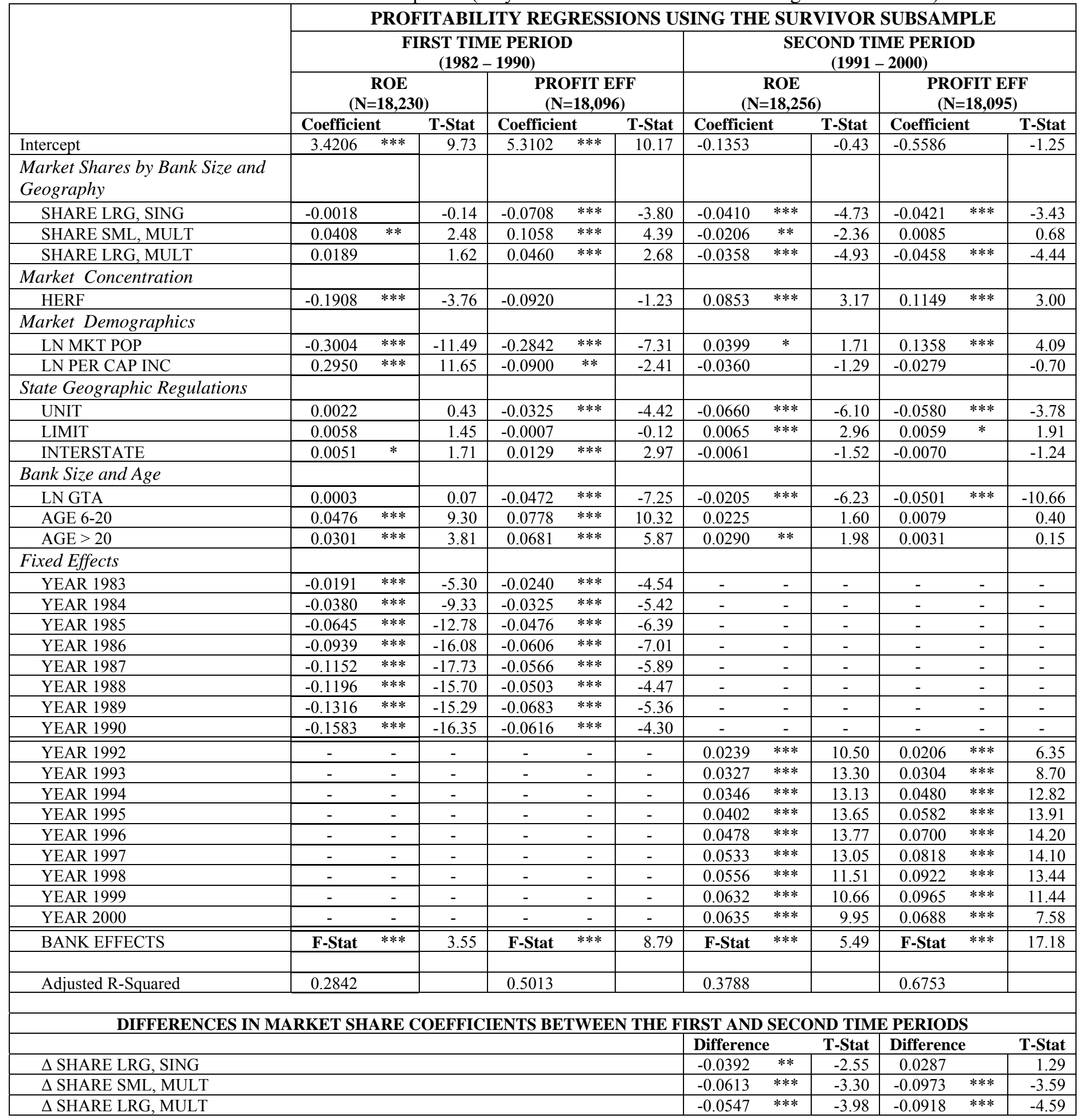


Table 4. OLS estimates from COST/GTA and Cost Efficiency performance regressions using the full sample of small, single-market banks. Data sets are unbalanced panels, 1982-2000. Superscripts *,**, and *** indicate significant difference from zero at 10\%, 5\%, and 1\% levels, two-sided. Bank fixed effects coefficients are not reported (only the F-stats for all bank effects together are shown).

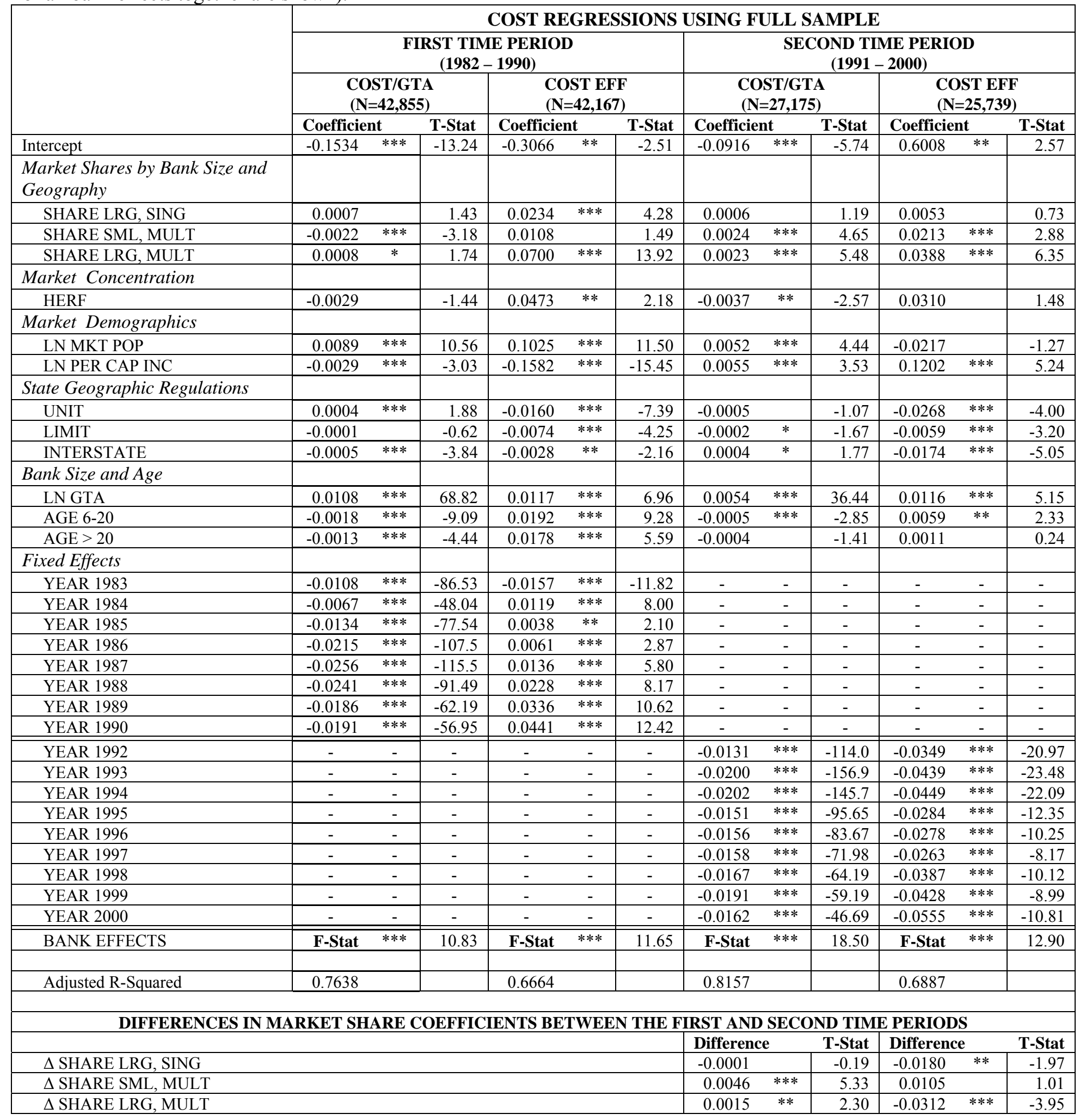


Table 5. OLS estimates from and COST/GTA and Cost Efficiency performance regressions using the "survivor" subsample of small, single-market banks that only includes banks present in at least 5 years of each time period. Data sets are unbalanced panels, 1982-2000. Superscripts *,**, and *** indicate significant difference from zero at $10 \%, 5 \%$, and $1 \%$ levels, two-sided. Bank fixed effects coefficients are not reported (only the F-stats for all bank effects together are shown).

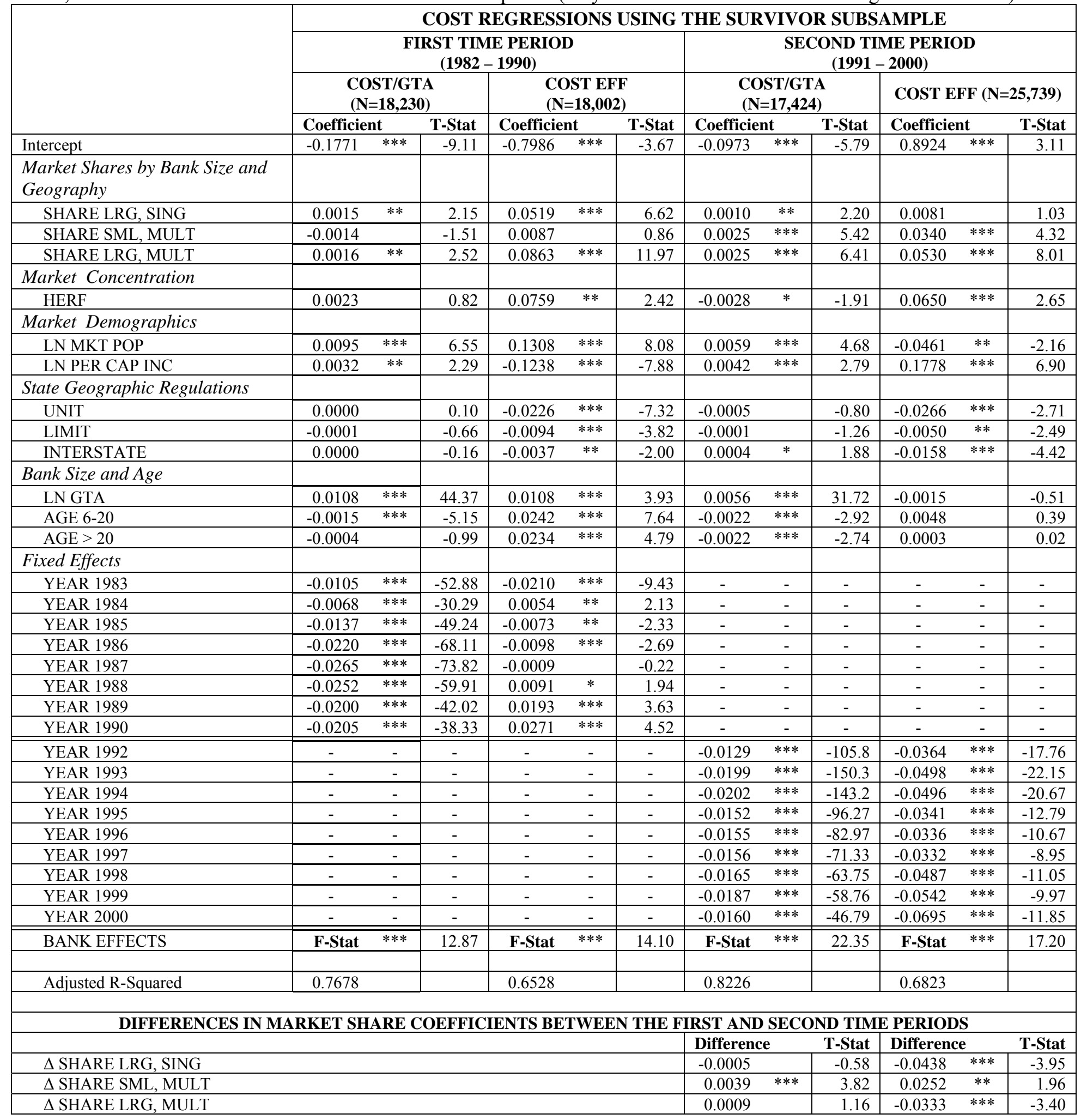


